\title{
Artificial corporatism: A portal to power for accountants in Brazil
}

Dr. D. Agrizzi

Southampton University

Management School

Highfield Southampton - United Kingdom

SO17 1BJ

Email: dila@soton.ac.uk

Dr. S. Sian (Corresponding author)

Queen Mary, University of London

School of Business and Management

Francis Bancroft Building

Mile End Road

London E1 4NS

Email: s.sian@qmul.ac.uk 


\begin{abstract}
The political history of Brazil includes a period of colonization by the Portuguese, the establishment of an imperial court, a period of rule by various military juntas, dictatorship and democracy. Drawing on archival based research conducted in Brazil and informed by theorisations of the contribution of interest governance to social order and corporatism, this study focuses on the transformation of the modus operandi of accountants and their ascendancy in this country. The study covers the period between 1902 and 1946, in which dictatorship, increasing centralisation and bureaucratisation eventually gave way to a fledgling democracy. Early in the twentieth century, the state pursued a policy of sponsoring the syndicalisation of workers as a means of eliciting cooperation in exchange for (what was essentially a simulacrum of) access. In accountancy, this early form of association was constrained in many ways, but it also laid the foundations for the accounting syndicates to press for legislation for improved education and for national professional organisation in 1946.
\end{abstract}




\section{Introduction}

Recent years have witnessed a proliferation in the literature pertaining to the professionalisation of accountancy. Although originally focussed on the development of the profession in countries where archival data was perhaps more readily accessible, for instance Britain, America, Australia, and Canada, this literature has also encompassed professionalisation stories originating in continental Europe (Caramanis, 2002; De Beelde, 2002; Ramirez, 2001; Rodrigues et al., 2003; Seal et al., 1996), Japan (Sakagami et al., 1999), China (Yee, 2009; Yee 2012), the Philippines (Dyball et al., 2007) and various former British colonies (Annisette, 1999 and 2000; Bakre, 2001 and 2005; Uche, 2002; Sian, 2006 and 2011; Verma and Gray, 2006). This latter category, in particular, has seen an escalation in contributions from researchers based in, or undertaking research in, the non-self-governing former British colonies. Whilst problems associated with undertaking such research in, what is now often classed as, the developing world have already been highlighted (Sian, 2011), it is fair to say that the (often) meticulous record-keeping of the servants of the imperial power both in Britain and her former colonies has facilitated the possibility of unearthing long forgotten data. This, in particular, perhaps accounts for the preponderance of contributions originating from the English-speaking world and the dearth of contributions from other expansive empires.

Redressing this imbalance a little, this study traces the emergence of professional accountancy in Brazil by drawing primarily from Portuguese language archival data, papers and the original relevant legislation. ${ }^{1}$ At the theoretical level, the literature pertaining to the professionalization of accountancy in an Anglo-American environment ${ }^{2}$

\footnotetext{
${ }^{1}$ The research was primarily conducted in Brazil. Libraries visited included: The National Library of Rio de Janeiro (Biblioteca Nacional do Rio de Janeiro); Library of Federal Senate in Brazilia (Biblioteca do Senado Federal in Brasilia); Library of the Syndicate of Accountants of the County of Rio de Janeiro (Biblioteca do Sindicato dos Contabilista do Município do Rio de Janeiro); Banco do Brazil archives (Arquivos do Banco do Brasil, in Rio de Janeiro); Library of the Regional Council of Rio de Janeiro (Biblioteca do Conselho Regional de Contabilidade do Rio de Janeiro); Library of the Regional Council of Minas Gerais (Biblioteca do Conselho Regional de Contabilidade de Minas Gerais); Library of the Regional Council in Brasilia (Biblioteca do Conselho Regional de Contabilidade in Brasilia); online Library of the House of Parliament (online Blibioteca da Casa Civil da Presidencia da República). These sources were then translated and cross referenced and checked against other available secondary data.

2 This grouping together does not suggest homogeneity and there is ample evidence that the model of British professionalization was subject to significant mutation when exported to the colonies (Chua and Poullaos, 1993).
} 
has drawn from conceptualisations to be found in the sociology of the professions literature (Larson, 1977; Macdonald, 1995) and within this context many authors have examined the state-profession relationship (Willmott, 1986, Richardson, 1989, Chua \& Poullaos, 1993; Roslender, 1992; Sikka \& Willmott, 1995a, 1995b; Walker and Shackleton, 1995). However, in Brazil, unlike (for instance) Britain, the state did not adopt a "laissez faire" approach to the creation of associations, there was no spontaneous organisation and accountants were not imbued with influence and status (Cooper and Robson, 2006). More akin to other centralised, authoritarian states such as Russia (Bailey, 1992), the Czech Republic (Seal et al., 1996) and China (Hao, 1999, Yee 2012) and also other continental European examples (Caramanis, 2002; De Beelde, 2002; Ramirez, 2001), the case of Brazil presents an opportunity to study institutional arrangements for professional accountancy in a setting, in which power-asymmetry in the state-profession relationship was a key influencing factor.

Within this context, the peculiarities of the case of Brazil also raise some interesting questions. Firstly, to what extent did structural changes in the economic, political and social environment in the period under study create opportunities for occupational ascendancy in accountancy? Secondly, the literature appears to suggest that centralised, authoritarian states are generally reluctant to delegate authority to occupational groups (Seal et al., 1996; Hao, 1999). ${ }^{3}$ So, why then is the case of Brazilian association different?

In order to address these issues within the Brazilian context, this study turns first to Streeck and Schmitter's study of the contribution of interest governance to social order. In particular, their identification of a fourth principle, associationism, is germane to an understanding of the relationship between the authoritarian state and accounting associations in Brazil. In conjunction with this, the paper employs a corporatist framework to facilitate an analysis of relations between the state and (accounting) occupational interest groups. The juxtaposition of two inter-related conceptualisations in this way has

\footnotetext{
${ }^{3}$ For instance, in the Czech Republic, Seal et al., (1996) note how state control was reasserted in 1972 and the Union of Accountants and Statisticians (established in 1969 after the Prague Spring) was disbanded and subsumed within the (state controlled) Association of Scientific Staff.
} 
precedence within the extant literature. Since the use of the concept of corporatism (and even the definition of it $)^{4}$ has engendered controversy, other critical writers, too, have drawn from supporting theorisations or utilised modifications (for instance, in the accounting-related literature see Richardson, 1989 and Yee, 2012).

Locating this study within the literature on the professionalisation of accountancy, potentially makes it an important contribution for a number of reasons: firstly, it focuses on a Latin-American country that is a former Portuguese colony and provides an interesting contrast to extant studies in the field, many of which capture aspects of the professionalisation process within an Anglo-American context ; secondly, it highlights the inextricable linkages between modes of governance and interest intermediation; finally, it sheds new light on the asymmetric state-profession dynamic by presenting a case that introduces a mode of occupational association (syndicalisation ${ }^{5}$ ) not commonly encountered in the accounting literature. In doing so, it builds upon an already expansive prior literature in accountancy that examines the relationship between the profession and the state, focussing particularly on periods of structural and socioeconomic change (Johnson, 1972; Chua and Poullaos, 1993; Walker and Shackleton, 1995; Zimmerman et al., 2006; Yee, 2012). The study also builds on more recent additions to the literature relating specifically to Brazil (Rodrigues et al., 2011; Rodrigues et al., 2012) and develops significantly the themes embedded therein. In doing so, it responds directly to calls for theorised "informative contributions on accounting's past in Brazil" (p.120) utilising archival data. ${ }^{6}$

\footnotetext{
${ }^{4}$ Panitch (1980) suggests that there remains some semantic confusion and theoretical diversity with respect to corporatism in the sociology literature. For a more detailed analysis of the varying definitions of corporatism in context see Walker and Shackleton, (1995, p.473). For an analysis of sub-types, see Schmitter 1979, p.20. For an alternative approach to corporatism (viewing it as political structure - within advanced capitalist economies) see Panitch,1979 and 1980.

${ }^{5}$ Where the state sponsors and supports the emergence of syndicates which are occupation-based representative associations.

${ }^{6}$ Rodrigues et al., 2011, is a research note that covers the period from 1860 to 1964 and distinguishes between periods of "waning liberalism", rising state corporatism and ultimately a populist democracy. Rodrigues et al., 2012, refers to the period of the Vargas regime with the intention of contextualising historical influences on the adoption of IFRSs in modern-day Brazil.
} 
The body of the paper is organised chronologically in two distinct periods of Brazilian history: before and after The Revolution of $1930{ }^{7}$ This is preceded by two sections that theoretically and historically contextualise the study.

\section{Governance, interest intermediation and accountancy}

In their seminal work, Streeck and Schmitter (1985a and 1985b) examine the way in which group interests are organised within society and how they are integrated into the policy process. They reiterate a general model to be found in the social sciences suggesting that modern societies can, at any moment in time, be analysed in terms of three major bases of social order: Community, with its guiding principle of spontaneous solidarity; Market, with its guiding principle of dispersed competition and State, with its guiding principle of hierarchical control (Streeck and Schmitter, 1985b, p.119). ${ }^{8}$ Social order, it is argued, is the product of the interaction, interdependence and linkages between these three orders and is subject to change over time in accordance with the rise, dominance and decline of each - the mix reflecting the mode of 'governance'. Alongside these three distinctive bases of social order, Streeck and Schmitter propose the existence of a fourth basis of social order as a means to understanding "bargained economies and societies": Association. 9 The central axis of the Associative order is the interaction between interdependent key actors (or complex organisations) which are defined by their common purpose of promoting and defending functionally-defined interests - this includes professional associations. The

\footnotetext{
${ }^{7}$ The period under study begins in 1902, which is significant as this was when the National Congress of Agriculture was convened by landowners to petition the government for the right to organise - a precursor to the syndicalisation of professional groups. It ends in 1946 with the creation of the CFC, the Conselho Federal de Contabilidade.

${ }^{8}$ In the 'community' ideal-type - communities are viewed as collectives who have leaders who "desire the esteem" of their followers, who, in turn, seek to belong to the group - where decisions are made by unanimous consent and members of which have a shared identity. In such communities there is the potential for conflict between group members and "foreigners" who are excluded (although communities may, by common consent, allow certain "foreigners" to join their ranks - in accountancy, for instance, see Sian, 2006). In the 'market' ideal - dispersed competition refers to the operation of the (economic market) as an ordering principle, in which entrepreneurs seek to maximise profits whilst consumers benefit from the creation of competition. Hierarchical control refers to the principle of social order organised via bureaucratic agencies. In the idea-typical state bureaucracy, "allocational decisions are made through 'public policies', with the ultimate backing of the state's monopoly of legitimate coercion" (legislation) (Streeck and Schmitter, 1985b p.121).

${ }^{9}$ Puxty et al. (1987) (and others) reject the associative principle as a mode of social order and refer to these arrangements as part of the 'community' basis. In their own work, Streeck and Schmitter note theoretical dissent with respect to the equation of Association with the other three orders (1985b, p.120-121).
} 
central guiding principle of the Associative order is that of organisational concertation, or negotiation between organisations (within given constraints) to reach and implement compromises or pacts pursuant to their interests. Such concertation requires that the interest associations represent the interests of and deliver the compliance of their membership and in order to achieve this they may seek/ or require the support or resources of the state (or state agencies), which alone can legislate to promote and protect negotiated positions. ${ }^{10}$

The Associative order, itself, can be further classified into ideal-types, the most commonly cited of which are pluralism and corporatism. ${ }^{11}$ Of these, corporatism is the strongest form of the Associative order, since it is so much more difficult to devolve tasks and ensure compliance in pluralist systems. In their framework, Streeck and Schmitter locate corporatism as a universal sociological principle of association, alongside community, market and the state (Cawson, 1985, p.1).

Corporatism is a specific socio-political process and as a concept, it is useful in analysing and explaining the relationship between the state and various interest groups (or quasiregulatory bodies). It is a form of interest intermediation, in which the interest group is granted certain rights and autonomy in return for adopting policies that advance the interests of the state. In accountancy, these rights can include the monopoly held by the professional association over audit work and, in some countries, self-regulation (Cooper et al., 1989). Corporative associations enter a process of deal-making eventually ratified by consensus, with the group leaders positioned between the members on one side and the state on the other. In the corporative-associative model the state delegates public policy functions to "the collective self-interest groups to create and maintain a generally acceptable social order" (Streeck and Schmitter, 1985b p.129).

\footnotetext{
${ }^{10}$ Monopoly status, guaranteed access, compulsory membership, centralised co-ordination, jurisdiction and control over member behaviour and delegated tasks of policy implementation are all dependent on the response of the state.

${ }^{11}$ Corporatist systems treat interest groups as legitimate participants in the policy-making process and decisions are made top-down through coordination and negotiation. Whereas in classic pluralist systems, interest groups are voluntarily organised, autonomous groups that represent the preferences of their membership and compete to exert influence over government policies to further their interests - decisions are made bottom-up and reflect the results of competition.
} 
In his 1974 contribution, Schmitter constructed his own definition of corporatism: "A system of interest representation in which constituent units are organised into a limited number of singular, compulsory, non-competitive, hierarchically ordered and functionally differentiated categories, recognised or licenced (if not created) by the state and granted deliberate representational monopoly within their respective categories in exchange for observing certain controls on the selections of leaders and articulations of demands and supports" (reproduced in Schmitter, 1979, p.13). Although instructive and often cited in the literature, this definition is an ideal-type (Richardson, 1989) and it has been extended to distinguish (by Schmitter himself and others) between different modes of corporatism. ${ }^{12}$ Although, corporatist arrangements exist (to varying degrees) in all nation states, ranging from liberal parliamentary democracies to authoritarian or communist states, a key elaboration of the concept differentiates between societal (or civil or liberal) corporatism and state corporatism. Both forms are based upon the premise of an institutional relationship between the systems of authoritative decision making and interest representation, but are the product of very different political, social and economic systems and very different constituent power relations. Societal corporatism is commonly associated with liberal, advanced capitalist, western democracies (Schmitter, 1979), where the state is perceived to be less interventionist and corporate bodies emerge within civil society - "out of an agreement between essentially voluntary interest associations to limit the conflict among their respective memberships and follow organisational developments in associational structures" (Coleman,1985 p.107). State corporatism is commonly associated with political systems that are authoritarian, single (or dominant)-party and repressive (Schmitter, 1979). ${ }^{13}$ In this setting, associations are adjuncts of the state and serve as an extension of the state bureaucracy, being directly incorporated into the

\footnotetext{
${ }^{12}$ Cawson (1985) distinguishes between the macro-level corporatism (exchange between the state agencies and "peak" organisations of labour facilitate national economic planning and control), meso-level corporatism (exchange between state agencies and more specialised interest associations at the sectoral level, such as trade unions) and micro-level corporatism (direct bargaining between state agencies and individual firms) (1985, p. 1-21). Referring to interest groups, Dedoulis and Caramanis (2007) distinguish between associationist bodies (which are self-governing and are oriented towards private purposes) and corporatist institutes (which are created and supervised by the state and are oriented towards public purposes).

${ }^{13}$ Regimes that have been associated with state corporatism include Salazar's Portugal (Rodrigues et al., 2003), Italy, France, Spain under Franco (French, 1991), China (Yee, 2012) and Brazil (Rodrigues et al., 2011).
} 
centralised hierarchical system of regulation, and employed by the latter as instruments in the pursuit of legitimation of their policies (Coleman, 1985; Puxty et al., 1987, p.284).

In his study of "Interest conflict and political change in Brazil", Schmitter (1971) identifies another dimension of state corporatism that is manifested in the Brazilian case and which he refers to as "artificial corporatism by means of preemptive co-optation". In this extension, the state sponsors and supports the emergence of representative associations (syndicates or occupation-based interest groups) before they can emerge themselves (Schmitter, 1971). ${ }^{14}$ As a result, out of a sense of gratitude almost for the 'generous outorga' (grant), the associations cooperated with the 'benevolent' central government that had birthed them and did not then act in a hostile and negative manner towards public authority. Thus, in creating a cooperative working class elite, the paternalistic State safeguarded the social order (French, 1991). Artificial corporatism by means of preemptive cooptation required the following to be in place: a set of legal norms governing the formation of representative associations; a set of rewards and punishments to reinforce the norms; sufficient authority to administer the rewards and punishments; and a set of institutionalised channels of representation that provide at least a semblance of access and accountability (Schmitter, 1971, p.112). As will be shown later, all of these conditions were in place in Brazil in the period under study.

\section{Accounting regulation and professionalisation}

Within the accounting-related literature, authors have utilised varying aspects of the conceptualisations examined above in order to analyse the state-profession dynamic, the rise of accounting associations and modes of regulation in accountancy (see also Cooper et al., 1989). In accounting regulation, a pure "State" approach (as envisaged by Streeck and Schmitter) emphasises hierarchical control in which the entire accounting process is controlled by the state through legislation and the regulation of authorised state or quasiregulatory bodies. Similarly, in a pure "Community" approach to accounting, the

\footnotetext{
${ }^{14}$ The pre-emptive thrust of the policy is supported by other authors and a more detailed analysis can be found in French (1991). It can also be compared with the situation in Argentina, where Peron had to deal with and co-opt an already existing set of class, sectoral or professional organisations.
} 
establishment of institutions, accountability and accounting procedures is left to private groups, such as self-regulating professional associations who are also responsible for the issue and enforcement of accounting rules. In contrast, a pure 'Market' approach would entail no discernible regulation of the accounting process with any emergent regulation relying entirely upon the demand for and supply of accounting information (Zimmerman et al., 2006). In reality, in accounting these bases of social order do not emerge in their purest forms (Puxty, et al., 1987) and regulation modes are subject to variation in structure and over time. ${ }^{15}$

Prior work has provided interesting insights into the rise, role and relations of professional accounting associations in both highly interventionist states and in more liberal democratic states. Guided by the work of Streeck and Schmitter, Hao (1999) highlights the emergence of the accountancy profession in a period of significant structural and political change in China and shows how, despite some erosion of state hierarchical control in the late 1970s, both market and community forces remained subordinate to the state. ${ }^{16}$ Similarly, Yee (2012) employs a corporatist framework, combining it with Gramsci's concept of hegemony, to examine the state-profession dynamic in China in the 1990's with a focus on intra-professional rivalry. Also set in a period of upheaval, moving from communism and centralisation towards democracy, Seal et al. (1996) employ Streeck and Schmitter's framework to show how accounting practitioners pursued the twin strategies of negotiating the regulatory power of the state whilst constituting a professional market in the Czech Republic (p.485).

\footnotetext{
${ }^{15}$ For instance, in Britain although the state was regarded as a neutral influence (Willmott, 1986) with respect to the activities of the early professional accounting organisations (at least until post WW1), there is evidence to suggest that this changed during the twentieth century (Johnson, 1982; Miller, 1990; Sikka and Willmott, $1995 \mathrm{a}, \mathrm{b})$ as accounting associations increasingly became a part of the mechanisms utilised by the state to regulate commercial activity, whilst at the same time acting in the interests of their members (Macdonald, 1995). Under Thatcher, The ICAEW, for instance, became a 'recognised professional body' under the Financial Services Act, 1986 (MacDonald, 1995, p.115).

${ }^{16}$ Hao (1999) does not specifically refer to the fourth basis of social order (association or organisational concertation), rather he refers to an accountancy "community" - a self-regulating community comprising members who share a common identity and values and whose leaders earn the trust and esteem of the community (p.287).
} 
Other studies have focussed on more liberal, capitalist societies. Thus, Walker and Shackleton (1995) examined the changing organisation of the British accounting profession during and after World War Two within the paradigm of British corporatism. In their study, Puxty et al. (1987) draw from Streeck and Schmitter's framework to examine and theorise the role of accountancy in regulating economic and social activities and the regulation of institutions of accountancy in the Federal Republic of Germany, the United Kingdom, Sweden and the United States of America. In a similar vein, Richardson (1989) focussed on the consequences of corporatist forms of public accounting regulation for the internal organisation of the profession in Ontario, Canada within the nexus of state, market and community forces.

What these studies show us is that corporatist concepts and the framework developed by Streeck and Schmitter (despite its noted limitations - see Puxty et al., 1987, p.274) provide an appropriate platform for the examination of regulation of accountancy and the emergence of professional associations by theorising the linkages between the principles of social order, the state and the role of interest groups as intermediaries. This approach is particularly pertinent to the current study where, in the period examined, hierarchical control dominated the other ordering principles and the state-profession dynamic was essentially an asymmetric one in which power resided with the (corporatist) state. By way of contextualisation, the next section highlights key economic and socio-political developments in Brazil's history.

\section{Historical context}

Brazil is an ex-Portuguese colony that has a history spanning colonialism, imperialism ${ }^{17}$ and (from 1889) autocratic rule. The First Republic, which has been characterised as a period of "waning liberalism and rising corporatism" (Rodrigues et al., 2011), existed between 1889 and 1930 in the form of a regionalised federation, administered centrally by

\footnotetext{
${ }^{17}$ Alvares Cabral is credited with claiming Brazilian land for Portugal in 1500, although other Europeans may well have arrived earlier. Brazil was ruled from Europe until Portugal itself was invaded by Napoleon in 1807, forcing King Dom João VI to transport his entire court to Rio de Janeiro (Fausto, 1999). The King returned to Portugal in 1814, after Napoleon's defeat, leaving his son as Prince Regent in Brazil. The latter broke ties with Portugal and established an independent imperial state. The emergence of the military as a force for change and the rise republicanism eventually lead to the fall of the monarchy and a military government was installed in 1889 (Fausto, 1999).
} 
the president, the legislative bodies of the Chamber, the Senate and the Supreme Tribunal (Poder Executivo, Legislativo and Judiciário) (Loewenstein, 1942). However, spiralling inflation and debt, a collapsing currency and the rise of communism created civil unrest, culminating in a series of strikes, rebellion in the army and eventually the 1930 Revolution that resulted in the installation of a military junta, which was replaced by the civilian government of Getúlio Vargas on 3 November 1930 (Fausto, 1999). ${ }^{18}$

In Schmitter's (1979) analysis, state corporatism is commonly associated with political systems that are authoritarian, single (or dominant)-party and repressive. In 1930's Brazil, supported by the military, and shaped by developments in Europe at the time (Mussolini in Italy, Stalin in Russia and the Nazis in Germany), Vargas presided over the inception of an authoritarian state that centralized power: the Estado Novo (new state). Patterned upon Salazar's regime in Portugal (Rodrigues et al., 2011), the Brazilian Estado Novo was legitimised by the inauguration of the 1937 Charter (Bak, 1985; French, 1991). The state employed the radio widely for political indoctrination (Schmitter, 1971) whilst censoring the media and supporting the development of the transportation network and communications as a means of facilitating the strong centralism that was imposed upon the nation (Burns, 1993; Flynn, 1978). All legislative bodies from Congress down to the municipal councils (municipalities corresponded to counties) were dissolved and Vargas intervened in the states ${ }^{19}$, removed governors and strengthened the central government by instituting a parliament consisting of a Chamber of Deputies and a Federal Council (Flynn, 1978; Loewenstein, 1942). The pattern of power changed under his regime and alongside the 250 traditional regional representatives, fifty representatives were drawn from industry, the professions, the labour force and the civil service to the Chamber of Deputies in an attempt to curb the influence of the rich states and the coffee interests (Burns, 1993). This co-dependence was a key feature of the Vargas regime and worked for both parties as

\footnotetext{
${ }^{18}$ Vargas first governed as chief of the provisional government (1930-1934), then as constitutional president elected by Congress (1934-1937), then as dictator (1937-1945) and finally again as an elected president (1945-1954) - his term ending with his suicide (Burns, 1993).

${ }^{19}$ Each of the 20 states administered its own services by raising local revenues. Under the new regime, the federal government could appoint an "interventor" (often associates or friends of Vargas himself) who was able to assume powers of the state executive or have power conferred directly by the president. In practice the states were reduced to "territorial subdivisions" and their rights to fiscal autonomy severely curtailed (Loewenstein, 1942).
} 
Vargas turned to elements of the middle classes and the proletariat for political support and in return, they were offered direct access to the state mechanism (Burns, 1993).

The expansion of education, ${ }^{20}$ the growth of markets and industrialisation in Brazil were the product of deliberate policies initiated and controlled by the state. International fluctuations in the price of Brazil's key export, coffee, and the loss of the monopoly on exportation of natural rubber at the turn of the twentieth century paved the way for the state-sponsored industrialisation of Brazil's export-oriented economy (Peláez, 1976; Goldsmith, 1986). Economically, the markets for several primary commodities collapsed in the Estado Novo period, enabling state power to penetrate yet further through the creation of specific institutes to control wages, prices, quotas and credit in the commodities' markets (in particular coffee, pinewood, sugar and salt). This bureaucratic control of the commodity markets through state institutes is another example of the centralisation favoured by Vargas' government. Streeck and Schmitter note that even the most 'etatistic' states require markets as a supplementary mechanism of allocation (Streeck and Schmitter, 1985, p.119b).

Societal reorganisation and structural differentiation accompanied economic growth and industrialisation in Brazil in the period under study. Between 1920 and 1940, there was a marked shift of the population out of agriculture into a variety of occupational fields, with a trend towards service or tertiary occupations. The period also witnessed a rise in urbanisation and although in 1920 the urban population was about $10 \%$ of total population, by 1940 this had increased threefold - contributed to by massive internal migration and immigration from abroad (Fausto, 1999). Accompanying this trend, as the economy "took off" bureaucratisation also increased rapidly in this period. ${ }^{21}$ As education became more widely available in the 1920 s and 30 s, the subsequent rise in social mobility alongside

\footnotetext{
${ }^{20}$ In 1934 the University of São Paulo was created and in 1935 the University of the Federal District. Between 1929 and 1939 there was a 60\% increase in the number of university students in the country. After January $1^{\text {st }} 1940$, only textbooks approved by the Ministry of Education could be adopted in schools and many were banned on political grounds - a means of controlling and shaping the "impressionable years of intellectual incubation" (Lowenstein, 1942).

${ }^{21}$ Empirical evidence suggests that during the Vargas years there were steep rises in numbers employed "in 1920, one out of every 195 actively employed Brazilians was in the federal bureaucracy. By 1940 this ratio had changed to one out of every 132, and by 1960 it was one out of every 65" (Schmitter, 1971, p.33).
} 
occupational diversity and increased urbanisation created fertile conditions for the rise of the corporative-associative order and the formation of occupational interest groups in nonagricultural sectors of the economy.

Streeck and Schmitter's (1985b) analysis refers to "advanced industrial/capitalist societies", so it does raise the question as to whether Brazil, in the period under study, fits this description. From the data presented in this section (and elsewhere), there is evidence that, despite strong state control, Brazil had a commercialised capitalist economy. Initially based on the export of various primary products to world markets and the exchange of goods between regions, it developed further as the Brazilian Government undertook a significant industrialisation programme - indeed it was the chambers of commerce (associações comerciais) that were amongst the first representative (non-agricultural) associations to appear.

\section{Pre-1930: Syndicalisation, differentiation and the rise of accountancy}

The above historical contextualisation, focusing on developments in state regulation and societal and economic change in the period under study, is salient in drawing attention to the linkage between governance, the maintenance of social order and, as will be shown, the appearance of intermediary interest groups in Brazil.

As early as 1891, the Federal Constitution granted the freedom of association and assembly. ${ }^{22}$ However, in line with the more liberal attitudes of the era, no explicit regulations were in place. In 1902, faced with a need to attract foreign labour, the national Congress of Agriculture was convened by landowners to petition the government for the right to organise. The outcome was a decree in 1903 (Decree 979, 06/01/1903) permitting mixed owner/worker organisations ${ }^{23}$, although in practice such arrangements tended to

\footnotetext{
${ }^{22}$ Prior to this the workforce was relatively undifferentiated and employer-employee relations often governed by the norms of slavery.

${ }^{23}$ The formation of merchant cartels (syndicates) for important commodities was encouraged as they eliminated competition and the fluctuations of the free market and brought the markets under government control. This was balanced by the introduction of cooperatives for the farmer producers - yet another means of facilitating control (Bak, 1985).
} 
favour employers. In 1907, this right to associate (form syndicates) was extended to other workers, including the liberal professions, authorising a degree of autonomy for syndicates and allowing voluntary membership (Decree 1.637, 05/01/1907). Article 8 (Chapter I) of this decree stated that: "the syndicates that establish themselves in the spirit of harmony between employers and workers, in other words those with permanent councils for conciliation and arbitration designed to settle disputes between capital and labour, will be considered legal representatives of the whole class of working men and, as such, will be consulted on all matters pertaining to the profession". This decree was an important development for two reasons. Firstly, it is possible, within this statement, to detect the hallmarks of corporatism as conceptualised in this paper. It reiterates the obligation of the state to consult with the workers through their representative bodies, facilitating the exchange of a legal monopoly on representation and access to decision-makers, in return for compliance. From the state's viewpoint it was a means of preserving social order in the face of conflicts between the working class and the ruling class. Secondly, it also established the federal government's capacity to legislate for labour, although it remained the only pronunciation on syndicalisation until the post-revolution period.

The employment of such legislative tools created the capacity of the ruling elite to mould the workers and command compliance, but was dependent upon a respondent workforce. Workers in low-status occupations had, perhaps, more to gain from acquiescence and forming occupational syndicates that would potentially afford them a more powerful voice en mass. At the turn of the century, sales, agricultural work or working in commerce (for instance bookkeeping) were seen as low-status (Bielinski, 2000). There was a perception that work such as bookkeeping and accounting did not require high levels of education and those employed in such a codified environment acquired their skill through practice (Leite, 2005), ${ }^{24}$ thus making this an occupational group ripe for syndication.

\footnotetext{
${ }^{24}$ In Brazil's colonial past the aristocracy sent their children back to Europe to be educated in law, medicine and engineering. Brazil's history of slavery and societal division impacted upon the type of work that the different classes could perform. Brazilian society was, from the early days of colonisation, a mixture of native Amerindians, African slaves and the colonising Portuguese, which was subject to race-based stratification with the ruling Portuguese in the highest positions (Burns, 1993). Manual and technical jobs were performed by the native people and slaves and high-skilled, intellectual occupations were performed by the higher classes, although attending university was a means of socio-economic ascension.
} 


\section{Bookkeepers in the private and public sector}

From the turn of the century to 1930, the combination of state-led industrialisation, increasing foreign debt and a heavier tax burden brought with it a demand those with bookkeeping skills. In the private sector, the providers of such specialist services were the bookkeeping ${ }^{25}$ practitioners who at the time produced basic accounting information and were also responsible for clerical services, such as registering and writing contracts, dealing with correspondences and acting as office managers (Lopes de Sá, 2008; Bielinski, 2000). Many worked for smaller family businesses, although the more experienced opened their own offices.

In the public sector, those with specialist accounting skills were even more sought after. In line with Streeck and Schmitter's framework, allocational decisions in Brazil's state bureaucracy were made through public policies enforced by legislation and supported by a civil service. Brazil had inherited a strong tradition of ministerial bureaucracy from its connections with the Portuguese Empire and bookkeepers were commonly employed in the Civil Service (Contabilidade Pública). They were charged with general control duties including the organisation, inspection and coordination of governmental accounting data, budgeting and taxation (Decree 7.751, 23/12/1909, Chapter V, art. 111; Chapter VI). There is some evidence that the Civil Service in Brazil historically suffered from insufficient technical education and professional training of its public officials (Loewenstein, 1942) and admission to public service was often the result of nepotism or social connection. This, combined with relatively low salaries, overstaffing and indifferent public opinion provided opportunities for routine corruption. ${ }^{26}$

\footnotetext{
${ }^{25} \mathrm{We}$ refer to these accounting practitioners as bookkeepers as this is the translation of the Portuguese term guarda-livros. The evidence suggests that many were highly experienced and undertook more complex work in addition to bookkeeping.

${ }^{26}$ In the post-revolution period, the State also instituted ranks for the civil service along with entrance examinations (in 1936) and financial control of the Civil Service was enhanced through the creation of the Departmento Administrativo do Serviço Público (under Article 67 of the Estado Novo), a new administrative department with responsibility for control over the annual budget and its implementation (Flynn, 1978).
} 
The state addressed the issue of poor education and training via legislative means and two schools of commerce were ordained public utility entities in 1905 (Decree 1.339, 09/01/1905) (Rodrigues et al., 2012). These schools had been established in Rio (Academia de Comércio do Rio de Janeiro) and São Paulo (Escola Prática de Comércio de São Paulo) since 1902 (Decree 4.331, 01/02/1902). Courses in accountancy were offered by the school ${ }^{27}$ and certificates were issued to bookkeepers (guarda-livros) and to those attaining the title of perito judicial - whose role was to verify and analyse accounting information and deal with the legal aspects of accounting by providing the judicial system with expert advice in cases regarding taxes and insolvency (Pires, 1999; Yoshitake et al., 2005). ${ }^{28}$

The archival evidence suggests that some of the bookkeepers in the Brazilian Civil Service were high-ranking servants of the state. In 1919, guidelines regarding general accounting procedures for governmental institutions were introduced via legislation and the General Directory of Accounting of National Treasury (Diretoria Geral da Contabilidade Pública do Tesouro Nacional) was established with the objective of supervising governmental accounting agencies (Decree 13.746, 03/09/1919). Initiated by the state, João Ferreira de Morais Junior (a bookkeeper who held a highly ranked position within the Government) was designated to organise and coordinate the project to facilitate the implementation of these guidelines assisted by Carlos Claudio da Silva (also a government employee), who became the bookkeeper of the Treasury. Together they developed and implemented instructions for a central double-entry system (Instruções para o serviço de escrituração

\footnotetext{
27 There are some traces of the colonial link to be found here. In Portugal, too, the development of accountancy was founded on establishing a knowledge base first. Rodrigues et al. (2003) refer in detail to the creation of a Board of Trade in 1750 to "foster commercial activity" and a School of Commerce in 1759. Interestingly, both countries hosted political dictatorships and were subjected to increasing centralist corporatist policies that favoured a strong state and a hierarchical societal structure. Portugal, too, had its own Estado Novo under Prime Minister Antonio Salazar, who was appointed in 1932. Under this regime free unions and professional associations were banned in 1933 and replaced with "National Unions" - a system not that different to the syndicates to be found in Brazil. Further comparison of the Brazilian and Portuguese cases can be found in Rodrigues et al. (2011, p.113).

${ }^{28}$ In practice the term guarda-livros was used by both those with educational certificates and those who had practical experience only. The term was replaced by Técnico de Contabilidade (Accounting Technician) in 1945 (Decree 8.191, 21/11/1945). The perito judicial were also referred to as the perito contador or the perito contábil. The term contabilista was a general term for practitioners and actuários were those involved in insurance. The word perícia is derived from Latin (peritia - knowledge acquired by experience). A perito needed to gain considerable knowledge about auditing and law (tributary, constitutional, criminal, administrative, civil and labour), as they assisted judges in judicial cases (Lopes de Sá, 2002).
} 
por partidas dobradas nas Contadorias Seccionais e na Contadoria Central da República), which became compulsory in 1922 (Decree 4.536, 28/01/1922). The "system" was intended to centralise accounting information in the Treasury Court, so that the regional offices could be controlled by the Treasury Board and was integral to the increasing centralisation and bureaucratisation in the country (Yoshitake et al., 2005). The introduction of such a system carried with it a need for those with specialist skills to operate it, thus strongly associating accounting practitioners with political positions.

In many cases to be found in the literature, the determined actions of individual accounting practitioners are often the driving force behind occupational organisation - as has been shown in other studies of centralised states where they may hold positions of power within Government (Bailey, 1992; Bunget et al., 2009; Zelinschi, 2009).29 In Brazil, high profile practitioners such as Francisco D'Auria, Paulo Frederico Hermann Junior and João de Lira Tavares also held high social positions and had gained reputations as bookkeepers in the government in São Paulo and Rio de Janeiro and harboured ambitions to raise the perceived status of those offering bookkeeping and accounting services. They had already achieved positions of trust within the centralised administration and were well positioned to assist in the creation of access channels between the accounting syndicates and the state. ${ }^{30}$

Although private businesses continued to be subject to the requirements of the 1850 Trade Code (Lei 556, 25/06/1850), further strict controls were imposed on governmental accounting procedures. In 1922, the Código de Contabilidade Pública (Code for

\footnotetext{
${ }^{29}$ For instance, Bailey (1992) describes the role played by prominent accounting practitioners in Russia between 1875 and 1931 and the founding of an accounting journal - the Schetovodstvo. In Romania, Grigore Trancu-lasi (an accountant working for the government) pushed through plans to create the Romanian Body of Experts and Chartered Accountants in 1921 (Bunget et al., 2009) and later leading figures of the Body of Alumni (graduates of the schools of commerce) were in positions of power and several were members of the Romanian Parliament. Their message was spread via their journal - the Review (Zelinschi, 2009).

${ }^{30}$ Journals and books relating to accountancy provided a platform for discourse and by the $1^{\text {st }}$ of January, 1912, D'Auria had launched the first issue of the first Brazilian accounting journal (Revista Brasileira de Contabilidade). From 1912 until 1920 this journal was owned by a publicly-traded company and by 1916 a second journal had been launched - Monthly Brazilian Accounting (Mensário Brasileiro de Contabilidade$M B C$ ) (MBC n ${ }^{\circ} 341$, August, 1945 p.295). By 1928, D'Auria had authored eight accounting books. Hermann Junior was D'Auria's pupil and soon became a reputable accounting practitioner, academic and a writer in his own right (Lopes de Sá, 2008). Lira Tavares was also a writer, a historian and accounting academic, bookkeeper at the Ministry of Finance and later a powerful Senator (Lopes de Sá, 2008; Peleias and Bacci, 2004; Centro de Memórias do CRCRS, 2009).
} 
Governmental Accounting) (Decree 4.536, 28/01/1922) was introduced, creating the Central Directory of Accounting of the Republic - Directoria Central de Contabilidade da República (DCCR), which was a source of regulations for the uniform preparation of accounts within all Brazilian governmental institutions (art. $1^{\text {st }}$ ) and also provided guidance on the work to be performed by those practicing accounting in the public sector. ${ }^{31}$

\section{The early syndicalisation of accountancy}

Bookkeepers and those offering accounting services possessed key skills which were valued by successive administrations committed to economic growth in the period under study. State recognition of those providing bookkeeping/accountancy services as a separate occupational form was important because it meant that they met the basic criteria for syndicalisation. From the State's viewpoint, for the purposes of governance, it was important to control workers and this was facilitated by organising them into occupational groups before they had an opportunity to do so on their own terms. Equally for the workers, as will be shown, syndicalisation brought related advantages.

In August of 1916 sixty bookkeepers gathered together in Rio de Janeiro to discuss the creation of the Instituto Brasileiro de Contabilidade do Rio de Janeiro, which was effected by September of that year. The creation of this body was the direct result of the 'encouragement' in a speech made by Senator João Lira Tavares on the $28^{\text {th }}$ of August, 1916 at the Federal Senate in Rio de Janeiro, where he espoused the need to regulate bookkeeping practices and urged bookkeepers to gather together to fight for 'protection' and recognition (Revista Brasileira de Contabilidade, 99, May/June, 1996, p.23; Lopes de Sá, 2008).

In the following year, 1917, as discussions regarding the amendments of the Brazilian Trade Code were taking place within the Congress, bookkeepers organised a public protest

\footnotetext{
${ }^{31}$ In addition to national and regional government departments, the regulations also applied to government companies such as Companhia Pastoril Mineira (milk from Minas Gerais); Companhia de Saneamento do Rio de Janeiro (sanitation); Sociedade Salinas Nacionais (salt); Companhia Cooperative de Carvão (coal); Companhia Nova Era Rural (rural agriculture); Companhia de Luz (light); Companhia Carries de Ferro (iron); Banco Constructor do Brazil (bank) - Source: Lists obtained from Banco do Brazil archives (Rio de Janeiro).
} 
demanding further intra-occupational separation: an official distinction between the functions to be performed by bookkeepers and perito judicial and clerks (Mensário Brasileiro de Contabilidade, Vol. 4 de 20-07-1917 p.77 - Biblioteca do Conselho Regional de Contabilidade do Rio de Janeiro). Perhaps inspired by the activity of accounting groups in Rio, and alert to the changing conditions for occupational groups in the country, a group of eleven young accounting practitioners from São Paulo sought to establish the Accounting Institute of São Paulo (Instituto Paulista de Contabiliade). The group included prominent practioners (such as Morais Junior, Hermann Junior and D’Áuria) led by Senator João de Lira Tavares and it became an accounting syndicate (Sindicato dos Contabilistas de São Paulo) on the $19^{\text {th }}$ of July, 1919 (Paleias and Bacci, 2004; RBC, 1996).

For the membership, syndication was a means of displaying occupational solidarity to negotiate better conditions and pay and (seemingly) obtain access to government favour. For the state, syndicates were adjuncts of the state machinery and a means of legitimation of state policies. In return for supporting the rise of occupational interest groups the government were assured, to some degree, cooperation and collaborative support. This became a particularly important means of leverage in the early the twentieth century, as worker unrest and strikes were prevalent throughout Brazil (Oliveira, 2005; Boito Jr., 1991). In accountancy, the creation of such regional associations (the most active being Rio de Janeiro, São Paulo and Minas Gerais), were also effectively a means of carving a jurisdictional space and potentially securing upward social mobility and associated rewards for the local bookkeeping/accounting community. Unlike the associational forms to be found in the Anglo-American model, where exclusionary closure is a pivotal part of the process, the syndicates were open to all practitioners in the region. The regional associations were perceived by the accounting fraternity to be their portal to power and in later years they did, indeed, play a role in moves towards national association, such that they were on a par with other traditionally respected professions such as lawyers, engineers and physicians ${ }^{32}$ (Lopes de Sá, 2008; Peleias and Bacci, 2004).

\footnotetext{
${ }^{32}$ A legal professional body, the OAB (Ordem dos Advogados do Brazil) was created within the revolutionary context of 1930 (Decree 19.408, 18/11/30). The first engineering professional body, the CREA(Conselho Regional de Engenharia) was created in 1934 (Resolução CFC no 2 de 23/4/1934) and a professional body
} 


\section{Using institutionalised channels of access}

The state had legislated for syndicalisation, which permitted open entry for practitioners to the occupational syndicate. However, amongst the membership of the accounting syndicates, there was dissatisfaction with the limited opportunities for education and training in commerce and there was a perceived need to protect the market for accounting services by restricting access to those with appropriate qualifications, rather than the open entry permitted by the legislation (Lopes de Sá, 2008). This tension culminated in the organisation of the First Accounting Congress held in Rio de Janeiro between $14^{\text {th }}$ and $27^{\text {th }}$ of August, 1924. ${ }^{33}$ The Congress was organised and coordinated by the Brazilian Institute of Accounting of Rio de Janeiro (Instituto Brasileiro de Contabilidade do Rio de Janeiro).

As in other centralised states, there is evidence that protagonists from within the state machinery - the "inside men" - played key roles in championing the cause of the bookkeepers in Brazil. They were successful because it was common practice for technical personnel (técnicos) to be co-opted to government agencies for long periods of time - a practice referred to and infiltração (infiltration). As Schmitter notes in his 1971 empirical study, "these economists, statisticians, engineers, accountants and lawyers continue to receive their associational salaries as well as their new official ones" (p.297). However, personnel were also transferred in the opposite direct, in a variation of (the French term) pantouflage, whereby civil servants in key positions were transferred to corresponding representative associations. The creation of "a set of institutionalised channels of representation that provide at least a semblance of access and accountability" (Schmitter, 1971, p.112) was a key feature of syndicalisation. Reflecting this and also the facilitating role of high-ranking bookkeepers in the Civil Service, the Minister of Finance, Rafael de Abreu Sampaio Vidal, was invited as a guest speaker to the First Congress (Lopes de Sá,

for physicians CRM (Conselho Regional de Medicina) was created in 1945 (Decree 7.955, 13/09/1945). Other occupations recognised as professions included economists, dentists and architects.

${ }^{33}$ A 800-page report of the Congress was published in 2 volumes, currently held by the accounting syndicate in Rio de Janeiro (Relatório do Primeiro Congresso Brasileiro de Contabilidade, Rio de Janeiro: Imprensa Nacional, 1927, 1929 - Biblioteca do Sindicato dos Contabilista do Município do Rio de Janeiro). During this conference, 75 different papers were presented and discussed in meeting, organised into four sections: general accounting issues; the regulation of accounting education; the regulation of the profession and related legislation. 
2008; RBC, 1996; Centro de Memórias do Conselho Regional de Contabilidade do Rio Grande do Sul (CRCRS), 2009). The first session was chaired by a high-ranking bookkeeper in the Civil Service, Francisco D'Auria, who was an active member of the accounting syndicate of São Paulo and who later became the Secretary of State (Masi, 1958). D'Auria was the former head of the double-entry commission of the Treasury and the Director of the Instituto Brasileiro de Contadores Fiscais (Brazilian Institute of Accounting Inspectors created in 1916) and the Instituto Brasileiro de Contabilidade do Rio de Janeiro (Brazilian Institute of Accounting of Rio de Janeiro) and the Associação dos Contadores de São Paulo (Accountants Association of SãoPaulo (also created in 1916) (MBC, 1917; Peleias and Bacci, 2004).

The conference was convened as a means to persuade the authorities of the need to progress towards improvements in the education of those performing accounting related tasks. This was high on the agenda since the registration of accounting information as well as the preparation of accounting reports was still seen as a job to be performed by the less skilled. ${ }^{34}$ Raising standards of education and hence competence were key to advancing the social status and remuneration of those offering bookkeeping and accounting services. The high profile nature of the 1924 Congress and the message from the accounting syndicates could not be ignored and convinced the Minister of Finance to consider new legislation, initially aimed at reforming training and education in commerce.

\section{Attempts to differentiate through education}

By 1926, the Brazilian Constitution was the subject of significant reform under the administration of the republican lawyer Artur Bernardes. The new constitution was drafted with a view to strengthen the autocratic control of the federal government over the regions and it was within this context, that new legislation was directed towards the reorganisation of education in commerce (Decree 17.329, 28/05/1926). The 1926 legislation established two courses in commerce - curso geral and curso superior and accredited the existing schools of commerce (such as Academia do Comércio do Rio de Janeiro, Escola de

\footnotetext{
${ }^{34}$ Comparisons can be drawn with other cases to be found in the literature, for instance in Russia, the First All-Russian Congress of Accountants was held in Moscow between 10-15 June 1909 (Bailey, 1992) and in Romania, the first Congress of Commercial Schools was held in 1906 to lobby for an elite body of accountants, improve education and establish an accounting journal (Bunget et al., 2009).
} 
Comércio Alvares Penteado, Academia de Ciências Contábeis de Alagoas), so they could officially offer such programmes. ${ }^{35}$ On completion of the curso geral participants were issued with an accountants' certificate, and were to be known by the term contador (replacing the term guarda-livros) (Aragon, 2009; Lopes de Sá, 2008). ${ }^{36}$ Those completing the curso superior were awarded a certificate of Graduado em Ciências Econômicas e Comerciais (graduate in Economics and Commerce). In the absence of a higher level course in commerce at this stage, these two courses became the foundation for those entering accountancy and the legislation had helped to put the accountants on a par with other occupational groups that required specific educational qualifications (Nagle, 1976).

Despite the move forward in education and increased codification, the economic environment of the time meant that the increasing availability of accounting-related jobs remained accessible to the less skilled and under privileged (Leite, 2005; Lopes de Sá, 2008), which accentuated the existing perception that accounting practitioners occupied a lower-status position compared to other professions. ${ }^{37}$

Tavares Lira, the elected President of the Conselho Perpetuo ${ }^{38}$ was formally recognised (on $25^{\text {th }}$ of April, 1926) by his colleagues for his effort in pursuing the interest of accountants within the government (Source: Portal do CRCRJ-Conselho Regional de Contabilidade do Rio de Janeiro). Through this body and the representation of their interests within

\footnotetext{
${ }^{35}$ Prior to the 1926 legislation, the Commerce Academy of Rio de Janeiro (Academia de Comércio do Rio de Janeiro) already offered a precursor to the curso geral, which was aimed at creating bookkeepers, perito judicial and preparing students to work for the Finance Ministry and the curso superior, which aimed to prepare students for Consulates and Foreigner Affairs and accounting roles in banks and large private business (Leite, 2005).

${ }^{36}$ Bookkeepers employed by the government held higher prestige (as such positions were held by members of privileged families) than those who worked for small-family businesses.

${ }^{37}$ Parallels can be drawn with other cases to be found in the literature, thus in Russia, central planning reduced accounting to a passive technical discipline, held to be within the grasp of any literate person and not a matter of expert knowledge (Bailey, 1992). Similarly, in the Czech Republic, the high degree of codification under communist domination contributed to the down-grading of the ucetni or bookkeepers (Seal et al., 1996).

${ }^{38}$ The Conselho Perpetuo (Perpetual Council) was formed in 1916 and its aim was to establish a platform for accounting practitioners to debate issues in bookkeeping, accountancy and related professional education (Masi, 1958; Journal Correio da Manhã, $\mathrm{n}^{\circ}$ 2, p.35, 20/05/1917). Such action was considered necessary because for a long time clerks (who mainly performed general tasks related to commerce, but in small-family businesses also performed accounting-related tasks) working in commercial institutions could claim that they were bookkeepers if they had accounting experience, despite having no formal training.
} 
government, the contadores (as qualified bookkeepers were now called) continued pressed for the exclusion of those who had not undertaken accounting courses but continued to perform accounting functions by virtue of their experience (still referred to as guarda-livros in practice). In support of their calls for differentiation and laying the blame with the guarda-livros and the perito judicial, they cited the rise in the number of insolvencies between 1925 and $1929^{39}$ (Lopes de Sá, 2008).

By 1927, many more new accounting associations were created around the country, such as the Association of Diplomas in Commerce of Bahia (Associação Baiana de Diplomados em Comércio); Campinas Association of Accounting (Associação Campineira de Contabilidade); and the Institute of Accounting of Minas Gerais (Instituto Mineiro de Contabilidade) (Lopes de Sá, 2008). In December of that year, Francisco D’Auria was honoured by colleagues for his leading role, and in his speech he called for the creation of a national accounting organisation to register new accounting practitioners and a General Register of Accountants (Registro Geral dos Contabilistas), as a means of potentially excluding unqualified practitioners (Biblioteca do Conselho Regional de Contabilidade de Minas Gerais).

\section{Post-Revolution: From occupational syndicate to national professional association}

Following the Revolution, the period between 1930 and 1945 charted a new political direction, the power of the oligarchies weakened and there was social upheaval and economic development under the regime of the president-dictator Getúlio Vargas (Williams, 2001). The Nova República (New Republic), or Segunda República (Second Republic), witnessed a period of intense industrialization driven mainly by government and multinational capital (Vianna and Villela, 2005). It also witnessed the rise of the working class, their migration to the industrial centres and related demands for better working conditions (Flynn, 1978). Presented to the population as a "paternalistic gift of a benevolent leader", Vargas' regime promulgated new social and welfare legislation such

\footnotetext{
${ }^{39}$ Even though the rise in insolvencies was partly the result of increasing interest rates and the restriction of credit imposed mainly to control spiralling inflation and a series of economic problems including an acute crises in industries such as coffee. By the end of 1929, 686 companies had become insolvent and closed down (Conniff, 1981).
} 
as the far-reaching Consolidation of Brazilian Labour Laws. Vargas realised the political and economic importance of grouping wage earners together and as part of these labour reforms his regime sponsored, created and supported the emergence of representative associations before they could self-organise, based on the reasoning that "structural differentiation had not yet proceeded far enough" (adapted from Schmitter, 1971, p.111112).

\section{Artificial corporatism in accountancy}

After the Revolution, the Ministry of Labour, Industry and Commerce (MTIC) was created in 1930 and it put in place a new "a set of legal norms governing the formation of representative associations" - a key construct of artificial corporatism (Schmitter, 1971, p.112). It replaced the 1907 legislation with a new syndicalisation decree in 1931, which introduced greater constraints than had previously been the case and proclaimed interest associations to be the "consultative organs" of the State (French, 1991). Under the syndicalisation decree of 1931, accounting syndicates (alongside other occupational associations) had to be free of political and religious ideology and needed prior approval, which would only be forthcoming if the association met with set standards and submitted annual reports on its activities. The legislation also introduced a syndical tax, a minimum wage and a system of labour courts for the resolution of disputes. To secure compliance, delegates from the MTIC (the Ministry) were required to attend meetings and regularly examine the books created by the syndicates.

Other key features of artificial corporatism, as defined by Schmitter, include the establishment of a set of rewards and punishments to reinforce the norms; sufficient authority to administer the rewards and punishments; and a set of institutionalised channels of representation that provide at least a semblance of access and accountability (adapted from Schmitter, 1971, p.112). These can all be identified in the Brazilian corporative associative model and specifically in the provision of accountancy services. Despite the constraints placed upon them by this legislation, syndication was incentivised in a number of ways. Firstly, the legislation required the recognised syndicates to be consulted via the MTIC regarding social and economic issues concerning their class interests - thereby 
providing a 'portal to power', or institutionalised channels access to the administration. Secondly, they were participants in the "councils of conciliation and judgement" for the resolution of labour conflicts. Thirdly, they had the authority to sign collective bargaining contracts with other syndicates, firms or individuals. Fourthly, they could apply to the MTIC for financial assistance and had the authority to collect syndical tax from the membership. Finally, the legislation forbade the firing of employees for membership in syndicates (Loewenstein, 1942; Schmitter, 1971). By 1934, the incentives were further enhanced as it was decreed that representatives from officially recognised associations constitute one-fifth of the Chamber of Deputies. These "rewards" were, perhaps, particularly advantageous for occupational groups with lower social status. From 1931 occupational associations became institutions inextricably linked to the state - adjuncts of the policy making process (Loewenstein, 1942). Ultimately this was a very asymmetrical relationship with the government taking penal action such as threats of dissolution and punishments such as fines against those not meeting the exacting standards. ${ }^{40}$

Syndicates were permitted to join together to form a federation and by the late 30 s the federations became the normal channels of representation for employers in commerce and industry. Many such associations had close links to the President himself as many of the elected leaders were associates of Vargas. The syndicates were required to cooperate with the authorities in the "development of social solidarity", to provide legal aid services for members and to promote conciliation in labour disputes. In 1943, the existing syndical legislation was consolidated, further still, within the Consolidated Labour Code. Although the syndicates were still the spontaneous creation of the workers, they were effectively controlled by the Government. Under Vargas, the link with the syndicates was strong (Flynn, 1978, French, 1991) and they were required to be registered with the Ministry of Labour: "with the institution of this registry, the entire life of the professional association will gravitate around the Ministry of Labour; in it they will be born; with it they will grow; beside it they will develop; within it they will be extinguished" (Schmitter, 1971, p.124).

\footnotetext{
40 There was a "whole network of national and regional councils for lawyers, physicians, accountants, engineers and architects, social workers and librarians. Membership in them is obligatory for practitioners, and they play a role as interest articulators; they also serve to "regulate and moralize" the professions" (Schmitter, 1971, p.203).
} 
Thus, although the bookkeepers had been able to form syndicates spontaneously, it was the Ministry of Labour that granted or withheld recognition and it was the Ministry that had to approve candidates, elections and budgets. Although Vargas's interest group sponsorship was exclusively that of artificial corporatism, some private associations already existed in Brazil prior to his regime. ${ }^{41}$ In the wake of the Labour reforms regarding syndicalisation, a new decree was passed allowing the President of the Republic to grant "to civic associations constituted for the defence and coordination of economic and occupational interests" the status of "consultative and technical organs" (Schmitter, 1971, p.124). There is evidence that the leaders of the syndicalised accounting fraternity aspired to achieve the civic association status (free of the tight constraints imposed by syndicalisation) afforded to other professionals such as the lawyers. Three key developments were required in order for this to be achieved: firstly, enhanced and standardised education for the syndicate membership; secondly, improved regulation for accountancy and bookkeeping; and finally, the creation of a national accounting association.

\section{Government reforms in education, 1930-1932: Implications for accountancy}

A key development in the early 1930's was the creation of the Ministério da Educação e Saúde (Ministry of Education and Health) led by Francisco Campos - (Decree 19.402, 18/11/1930; Mcoy, 1959; Burns, 1993). The Ministry was responsible for initiating the Reforma Francisco Campos (Francisco Campos Reform), 1930-1932, detailing changes to the national structure of higher level education (Leite, 2005).

To coincide with these national reforms, the syndicate ${ }^{42}$ leaders (led by Lyra Tavares) organised a second Congress (II Congresso Brasileiro de Contabilidade) held in Rio de Janeiro (between $18^{\text {th }}$ and $25^{\text {th }}$ of April 1932). With a view to civic association status, they

\footnotetext{
${ }^{41}$ The oldest private association, the Institute of Brazilian Lawyers (IAB), was founded in 1843. Other middle sector non-government associations included the Clube de Engenharia in 1880 (which played a role in pressing for industrialisation), the Clube Naval in 1884, the Clube Militar in 1887 and the Brazilian Press Association in 1908 (Schmitter, 1971).

${ }^{42}$ In the early thirties various new regional accounting associations emerged: The Associação Mineira de Contabilidade (Accounting Association of Minas Gerais) was established in 1932 led by Antonio Miguel Pinto, a reputable accounting author and the Instituto Rio-Grandense de Contabilidade (Institute of Accounting of Rio Grande do Sul) was founded in 1933, led by the accountant Henrique Desjardins (Biblioteca do Conselho Regional de Contabilidade de Minas Gerais; Peleias and Bacci, 2004).
} 
called for further development of accounting in terms of education, training and regulation and the need to pressurise the government to legislate for the exclusion of those without formal qualifications (Biblioteca do Sindicato dos Contabilista do Município do Rio de Janeiro); Lopes de Sá, 2008; Peleias and Bacci, 2004).

Recognising the value of accounting services as a means of control in a period of rapid industrialisation, the Vargas regime initiated new accounting-related legislation to coincide with the national education reforms. The 1931 decree established guidelines for the reform of the education of accountants and introduced a new two-level course in commerce (articles $1^{\text {st }}$ and $2^{\text {nd }} \S b$ and $e$ of Decree 20.158, 30/06/1931). Secondly, the decree also established the Superintendência de Fiscalização dos Estabelecimentos de Ensino Comercial-SFEEC (Superintendence of Inspection of Institutions of Education in Commerce), subordinated to the Minister of Education and Public Health (article $34^{\text {th }}$ ), as a means of regulating the schools of commerce ${ }^{43}$ to ensure that they met a national standard (set in the articles $1^{\text {st }}$ and $2^{\text {nd }}$ of the decree) and that only those who had obtained accounting certificates issued by the schools of commerce should be accredited by the SFEEC (Decree 20.158 of 1931, Section III, article 54) and be entitled to call themselves contadores.

The 1931 Decree also ordained that bookkeepers qualified only by experience (i.e. those who had not attended any accounting academic programmes) should be registered with the SFEEC and be encouraged to take and pass the accounting examinations ${ }^{44}$ set by this institution within one year from the publication of the decree (article 55). On one hand this legislation restricted the practise of accountancy to those who had specific qualifications, but it also provided practitioners (who had not attended accounting courses before) with the opportunity to qualify as contadores. This generated immense debate amongst accounting practitioners, some of whom disputed the idea of the need to undertake exams to obtain an accounting certificate to be entitled to practice. Perhaps fearful for their

\footnotetext{
${ }^{43}$ In 1905 , there were only two institutions offering higher level commerce courses to 343 students. By 1926 this had risen to 11 institutions and 1,865 students and by 1930 there were 145 institutions and 15,500 students (Werebe, 1970, p.165).

${ }^{44}$ The accounting examinations set by the SFEEC included verbal and written examinations in Portuguese in subjects such as Mercantile Accounting, Commercial Mathematics and Commercial Legislation (article $55)$.
} 
livelihoods, this group argued that the experience they had gained during the years working as accounting practitioners should be sufficient to officially become a contador (Revista Paulista de Contabilidade, 1932) - a situation that resonates with other cases to be found in the literature (for instance, see Sian, 2006).

The introduction of the 1932 Decree $(21.033,08 / 02 / 1932)$ redefined the boundaries for the registration of accounting professionals. It stated that all accounting books (or other documents required by the Commercial Code), would not be legitimate unless signed by a practitioner registered by the SFEEC (article ${ }^{\text {st }}$ ). It also made it possible for accounting lecturers, employed by schools officially recognised by the SFEEC to register too (section III, article 2nd). Significantly, practicing accountants working for governmental, nongovernmental or private institutions for at least five years and those who had previously been authorised to sign a laudo pericial ${ }^{45}$ were also included within the scope of the new decree (sections VIII and IX article $1^{\text {st }}, 2^{\text {nd }}$ ). Despite the new requirements, experienced practising bookkeepers, who worked for governmental institutions and did not seek registration at the SFEEC, were entitled to remain in their positions (article $2^{\text {nd }}$, section IX, $\S 1^{\text {st }}$ ). Although not satisfying the call for differentiation between the qualified and unqualified practitioners, the legislation was a move towards raising standards for newcomers to accountancy, and therefore potentially the future occupational status of the group.

In the Brazilian case, the state initiated association and responded to calls from the syndicates for raised standards of education. As Schmitter suggests, this was a means of eliciting loyalty from the interest groups it had "birthed" in return for the support of the membership operationalizing legislative enunciations and compliance with state policies with regard to business and commerce - thereby facilitating, further still, the bureaucratisation and centralisation that is characteristic of state corporatism. The establishment and legal formalisation of the knowledge base for accountancy were also positive moves forward for national association.

\footnotetext{
${ }^{45} \mathrm{~A}$ document containing the result of a perícia contábil - a methodological investigation of accounting information relating to a particular judicial case (Lopes de Sá, 2002).
} 


\section{Towards professional organisation: 1933-1946}

A new constitution was introduced in 1934, reflecting the social transition and upheaval in the country, ${ }^{46}$ it recognised the syndicates and associations by law (art. 120, page 37), decreeing that the Government would establish good conditions for workers both in rural and urban areas and uphold the protection of workers and their rights (art 121, page 37). It also explicitly prohibited salary differences for the same positions $\left(\S 1^{\circ}\right.$, item a, art. 121 , page 37), established a minimum wage, a maximum eight hour working day and the right to holidays for all workers (items b and c). The new terms applied to all professions (item i), regardless the nature of the work whether manual, technical or intellectual $\left(\S 2^{\circ}\right)$. Although innovative, it remained in place only for three years as following the coup d'etat in November, 1937, a new constitution was introduced.

For the next seven and a half years the country experienced the rule of an overtly totalitarian government (Flynn, 1978; Loewenstein, 1942). The Estado Novo (New Estate) was regarded by some to be a very damaging period (Flynn, 1978; Loewenstein, 1942; Spiegel, 1949) as constraints were introduced upon foreign investment in water, power and mining, banks and insurance companies, and public utilities (Spiegel, 1949). The period also included the beginning of WWII and in Brazil there was a decrease in agricultural exports such as coffee, cotton, sugar cane, rubber and cocoa, which initiated a government-led drive to increase the internal production of goods previously imported through the development of local industry (Skidmore, 1999; Anuário Estatístico do Brasil, 1939-40, 1941-45; Boletim Estatístico do Brasil, 1946).

In addition to the occupational syndicates, the Vargas regime prioritised the need for technical advance and had instituted specialised assemblies and committees of those suitably qualified to provide technical advice to the administration (Rodrigues et al., 2012).

\footnotetext{
46 The new constitution coincided with the third Accounting Congress (III Congresso Brasileiro de Contabilidade), held between $21^{\text {st }}$ and $26^{\text {th }}$ of May, 1934, in São Paulo and led by Hermann Junior, which addressed the need to constitute a permanent commission and reinforced the need to pursue the development of accounting education (Peleias and Bacci, 2004).
} 
The creation of vehicles, such as councils and assemblies, to link the associations to the state machinery were attractive to the leaders of the syndicates (essentially nonremunerated roles), as they provided an opportunity for lucrative appointments and personal incentives for these leaders, many of low-status origins. It has even been argued that, possibly, "participation in leadership roles (had) been more important in stimulating associability than the various incentives for ordinary membership" (Schmitter, 1971, p.126).

Amidst social upheaval and political change, a fourth Accounting Congress (IV Congresso Brasileiro de Contabilidade) of the accounting syndicates was convened between $5^{\text {th }}$ and $11^{\text {th }}$ of September, in 1937, in Rio de Janeiro (Minuta do IV Congresso Brasileiro de Contabilidade, 1937). The Congress had a number of objectives, ranging from technical accounting issues to the regulation of commerce. ${ }^{47}$

In recognition of the concerns and recommendations of the Congress and faced with a skills shortage in a period of industrialisation, the Government initiated changes to the Commercial Code which revised the role of the perito and new legislation was introduced in 1940 to regulate public companies. ${ }^{48}$ On the education front, it subsidised private initiatives to deliver the cursos comerciais técnicos (technical courses in commerce). It was within this context that the Serviço National de Aprendizagem Industrial-SENAI (National Training Service in Industry) and the Serviço Nacional de Aprendizagem do Comércio SENAC (National Training Service in Commerce) were created (Decree 4.048, 22/01/1942 and Decree 8.622, 10/01/1946, respectively). The popularity of these institutions increased

\footnotetext{
${ }^{47}$ These included the standardization of the balance sheet; a review of education in accounting and titles bestowed upon those completing such courses; the pursuit of official recognition for a national professional body and improvements in the legislation in commerce (Peleias and Bacci, 2004).

48 In 1939 (Decree 1.608, 18/09/1939) changes to the Commercial Code (article $1^{\text {st }}$ ) officially defined the role of the perito as assisting judges in legal matters, whenever the object of the analysis involved commercial transactions (Titulo V, article 48, $\S 1^{\text {st }}$ ), such as payment of taxes and/or insolvency (article 499; 907). In 1940, the Decreto-Lei 2.627/40 introduced the first regulations for public companies in Brazil (Lei de Sociedade por Ações do Brasil). Relating mainly to technical issues, it also established new rules for assets valuations, profit distribution and standards for the publication of accounting reports. A further piece of legislation in the same year, the Decreto-Lei 2.416/40 (Contabilidade Pública dos Estados e Municípios), approved the application of uniform accounting codes to be applied to Brazilian governmental institutions, which had been defined during previous accounting conferences.
} 
as apprentices, from less privileged families, were directed to SENAI by the industries that employed them, so they could receive financial aid while attending courses (Werebe, 1970).

Further new legislation in 1945 (Decree 8.191, 20/11/1945) made it compulsory for those wishing to seek employment in governmental institutions as public sector accountants to undertake academic study. ${ }^{49}$ Following these reforms, three levels of accounting practitioners existed and were defined as bookkeepers (guarda-livros), accounting technicians (técnicos em contabilidade) and accountants graduated by university (contador):

1) Level 1: Bookkeeper (guarda-livros), awarded to those who had gained experience via the daily practices and no formal education in accounting whatsoever.

2) Level 2: Accounting Technician (Técnico em Contabilidade), awarded to those who were certified by an accounting school, which provided further-level professional courses in accounting.

3) Level 3: Accountant (Contador), awarded to those who had graduated from university.

\section{Creation of a national professional association}

The regionalised accounting syndicates had sought to advance their own status as a differentiated group and in conjunction with the state, a programme of specialist education and the enhanced regulation of technical aspects of accountancy and providers of services had successfully been achieved. In Brazil, 1945 was important as it was the year that saw the transition from the Estado Novo to a new democratic era which marked the country's engagement with worldwide capitalism. In this environment a new solidarity amongst occupational groups emerged as they pressed for greater freedoms and in the case of

49 The first higher-education course in accounting was launched in São Paulo, the Curso de Ciências Contábeis e Atuariais (Course in Accounting Science and Actuaries) (Decree 7.988, 22/09/1945, chapter I, article $1^{\text {st }}$ ) which issued successful students with certificate in BSc in Accounting and Actuaries (Chapter IV, article $\left.5^{\text {th }}\right) .^{49}$, when the Faculdade de Economia, Administração e Contabilidade de São Paulo (FEA) was created (Decree, 15.601 of 1946). For many decades, accountancy had been deemed an integral part of Economics (Decree 20.158 of 1931, section VIII, article 28). 
accountancy, the syndicates set out to raise the status of the occupational group such that it was on a par with other more established professions.

Although the literature suggests that it is difficult to define the point at which an occupation becomes a profession (Carnegie \& Edwards, 2001), in many instances it is recognised that the creation of a professional association is a key step in this process. In 1945, the president of the accounting syndicate of Rio - Morais Junior supported by Senator Raymundo Miranda and the accounting syndicate of São Paulo, were at the forefront of this process. Morais Junior sent a telegram (dated 24 September) to all accounting syndicates in Brazil urging them to attend an urgently-called accounting meeting, the First National Convention of Accounting (Primeira Convencão Nacional de Contabilistas), to be held between $10^{\text {th }}$ and $13^{\text {th }}$ of October, 1945.

In reality, and in line with features of the associative order and artificial corporatism, the system operating in Brazil in this period was one of mutual convenience and accommodation, in which the state offered patronage in exchange for political support to maintain the extant status quo. Through the process of syndicalisation, there were opportunities for syndicate leaders of lower-status origins to be co-opted into higher positions in the social order, particularly as political criteria were operative in the selection of civil servants (Schmitter, 1971). These appointments were the means by which syndicates interacted with the Administration and ultimately had input into its decision making process to their own (and their syndicate's) advantage as far as possible - they were "inside men". This help to explain how the bookkeepers were able to access the very highest levels of the administration. Getúlio Vargas, the President, was invited to the First National Convention of Accounting, as guest of honour, along with the minister of Education - Gustavo Capanema.

At this convention, the strategy entailed persuading Vargas and Capanema to endorse the draft plan for the creation of the first national accounting body and required a unified voice to be heard at the congress and a high attendance as a show of support. The strategy was successful and draft plans were approved on the $25^{\text {th }}$ of May, 1946 for the creation of a 
national professional accounting association. The project was legally sanctioned on the $27^{\text {th }}$ of May (Decree-Law 9.295, 27/05/1946) and gave birth to the CFC, the Conselho Federal de Contabilidade. However, within this period Vargas was deposed and replaced by President Eurico Gaspar Dutra, who, fortunately for the accounting practitioners, belonged to the social-democratic party and had declared his intention to promote economic nationalism and industrialization and continue to support the development of professions and education.

The first CFC committee ${ }^{50}$ consisted of nine members and included many of the highprofile practitioners who championed its realisation. Paulo Lyra de Tavares was the first CFC president to be nominated and appointed by the Dutra Government, which had retained legislative powers to do so. Committee members were appointed via an assembly formed by representatives of the regional syndicates, with each representation composed of three members (two accountants and one bookkeeper). In total, two thirds of the CFC members were accountants and one third bookkeepers (art. $4^{\text {th }}$, items a and b).

The original plan established by the 1946 decree and discussed by the third CFC meeting on the $11^{\text {th }}$ of October of the same year was to create a branch of the CFC in each region of Brazil (CRC - Conselho Regional de Contabilidade). ${ }^{51}$ In order to facilitate this, a commission of accounting professionals led by reputable accounting authors Manoel Marques, Jose Dell'Aurea and Brito Pereira was established (Resolução CFC no $3,29^{\text {th }}$ October, 1946). It was envisaged that the CRCs would fall under the control of the national CFC, originally located in Rio de Janeiro (although it was transferred to Brasilia, when the city became the capital in 1964). Once the CRCs were created, they first directed attention to the legal registration of accounting professionals, so only those registered could sign

\footnotetext{
${ }^{50}$ The members were: Paulo Lyra de Tavares, Francisco D’Auria, Antonio Miguel Pinto, Pedro Pedreschi, João Ferreira de Moraes Júnior, Ovidio Paulo de Menezes Gil, Manuel Marques de Oliveira, Jose Dell'Aora and A.A. de Brito Pereira.

51 There are currently 27 CRCs offices within Brazil and 416.405 professionals registered (222.998 contadores and 193.407 técnicos de contabilidade) as at 31/12/2009 (CFC). Qualification exams were introduced in 1999 (Res. CFC $\mathrm{n}^{\circ}$ 853/99) and the qualification certificate became a prerequisite for registration with the CRCs (Resolução $\mathrm{CFC}^{\circ}{ }^{\circ}$ 928/2002).
} 
accounting reports. Registration has been viewed in the literature as a key point in the professionalization process as a means of obtaining a legal monopoly (MacDonald, $1985) .52$

\section{The context within which the CFC was established and the consequences}

The creation of the CFC occurred in a period of political transition, from the authoritarian government installed by Vargas to the rule of Dutra, which signalled a more democratic era (Tavares, 1972; Vianna and Villela, 2005). At this time, the middle classes (concentrated in the industrial areas, such as Rio de Janeiro and São Paulo) began to demand rights to better working conditions, participation in wealth, a better quality of life and education as a means of social ascension (Skidmore, 1999). Responding to such calls the new president's agenda prioritised health, education and transport and the number of universities increased from five to thirty-seven during the period between 1920 and 1946 (Leite, 2005). To some extent, the professionalisation of Brazilian accountancy, it would seem, rode on the back of 'manpower policy' and 'educational policy' servicing the labour requirements of a changing economy. However, this was only possible because under Vargas the syndicates flourished, seemingly as a means of rooting the regime's power. However, in reality allowing the syndicates access to power also planted the seeds that would grow into the movement for national association.

The creation of the CFC also coincided with the installation of a new constitution in 1946 and an expanding economy after World War II - Brazil ranked tenth among the largest economies by 1960 (Colistete, 2007). Multinationals began to establish themselves in Brazil in the 1940's to take advantage of the more open economic conditions and with them came their Anglo-American auditing firms (Price Waterhouse; Arthur Andersen, Ernst \& Young, $\mathrm{KPMG}){ }^{53}$

\footnotetext{
52 The issue of the registration of professional accountants has been a point of contention in some professionalization projects (for instance Britain, where bills for registration were promoted by the accountancy bodies in the face of government hostility), whilst in others a positive attitude towards registration has prevailed as a means of controlling and standardising accountancy practice (Johnson, 1982; Johnson and Caygill, 1971).

${ }^{53}$ The first auditing firm established offices in Rio de Janeiro in 1902 (Mc-Auliffe Davis Vell \& Co - later Arthur Andersen) and the second in 1905 - Price Waterhouse. In 1957 the Institute of Public Accountants of São Paulo (Instituto dos Contadores Públicos de São Paulo (ICPSP) was created and later became the
} 
Although the introduction of the 1946 decree was the denouement of the process, it failed to organise the tiered profession on a task-basis and effectively bookkeepers, accounting technicians and accountants were perceived as performing the same tasks (Leite, 2005, p.113; Lopes de Sá, 2008). One might speculate that a centralist government seeking to develop and bolster the quantum of accounting expertise would not necessarily have been sympathetic to the demands of the practitioners to close off or restrict opportunities to potential entrants in order to achieve greater differentiation.

\section{Conclusions}

This study has brought together concepts of state, societal organisation and the role of interest groups in governance. It is set in Brazil, in a period when the state was the dominant driving force behind industrialisation and commercialisation, creating a more urbanised and occupationally diversified society in the process. Having dispensed with both the multi-party system of politics and a single-party democracy, the only alternative for the authoritarian state was to seek legitimation via sources of democracy in organised classes. To that extent, the case of Brazil coincides with descriptions to be found in Streeck and Schmitter's framework (and adopted in this paper) which suggests that "in the ideal-typical state bureaucracy, allocational decisions are made through public policies that are enforced with the ultimate backing of the state's monolpoly of legitimate coercion" (Streeck and Schmitter, 1985b , p.121).

At the turn of the twentieth century, the Brazilian state legislated for the formation of various occupational syndicates before they could "form naturally" - a process that we have referred to in the paper as artificial corporatism by means of preemptive co-optation. In this system, the syndicates (and eventually the small number of private associations) were used as conduits for the transmission of Government policies and the dissemination

\footnotetext{
Instituto dos Contadores Públicos do Brasil (ICPB). In 1960 the Institute of Internal Auditors of Brazil (Instituto dos Auditores Internos do Brasil- AUDIBRA) was founded and, in 1968, the Brazilian Institute of Independent Auditors (Instituto Brasileiro dos Auditores Independentes,- IBAI). The Institute of Independent Auditors of Brazil (Instituto dos Auditores Independentes do Brasil-IAIB) was founded in 1971 and it became the Brazilian Institute of Accountants (Instituto Brasileiro de Contadores- IBRACON) in 1982.
} 
of authoritative edicts to firms, organisations and individuals (Schmitter, 1971, p.299). However, the system was essentially one of mutual accommodation where the co-opted entities were linked to the state machinery (via various councils, commissions and working groups) through institutionalised channels - a portal to power.

The study utilises these conceptualisations to show how one such occupational group, those providing accounting services, were subject to this form of association in Brazil. The evidence presented in this study highlights the practical operationalization of artificial corporatism: firstly, early syndical legislation was developed significantly under the Vargas regime; secondly, there was a series of rewards and punishments to reinforce the dictates established, as evidenced by minimum labour rates and working conditions, punitive punishments and threats of dissolution; finally institutionalised channels of representation that provided at least a semblance of access and accountability were in place. These channels presented the regionalised accounting syndicates with an opportunity to seek to advance their own agenda within the set constraints to eventually be on a par with other professions. The strategy to achieve this required a specialist education and training to be in place, a means of excluding those who had not met the required standards of competence, and, ultimately, national association. Contextualising this study through societal, political and economic change is important in helping to explain why national institutional arrangements for accountants were effected at that particular time and how the strategy was effected.

A key contribution of this study is the introduction to the accounting literature of new empirical data that helps to extend our understanding of the nature of the state-profession axis by presenting a new dimension in state-profession relations. Extant examples in the literature tend to focus on the spontaneous rise of associations from within civil society and where the state has legislated for professional organisation (for instance in many excolonies or continental Europe), there is evidence that it has done so at the behest of the existing accounting community. Syndicalism defies this pattern and was established in Brazil with a view to creating an environment within which associationism was a cultural norm and interest groups were integrated into the state mechanisms. Although forms of 
syndicalism existed in other regimes, for instance Portugal under Salazar, its role in interest representation, governance and intermediation has not, thus far, been examined in detail in the accounting-related literature. The case of Brazil, as analysed here, also supports evidence found in the accounting-related literature pertaining to centralised states, where protagonists from within the state machinery - the "inside men" - played key roles. In Brazil, they were successful because infiltration was common practice for technical personnel (co-optation to government agencies for long periods of time). Thus, the channels or portals were not only the main routes for the two-way transfer of personnel, but also an important route for the flow of the patterns of influence.

Despite the noted differences, the evidence presented here also suggests that there are also commonalities to be found with the Anglo-American model of professionalisation. Firstly, the occupation-based Brazilian syndicates were the product of government legislation and were not selective in terms of entry, resulting in a varying quality of service providers. As in other models, those with high accounting-related educational qualifications sought to exclude those with no formal education (qualified through experience). Secondly, striving for a specialist education for accountants was important as it was a means of protecting the jurisdictional space from encroachment by other professionals, such as engineers, who if proficient in accountancy could apply for accounting roles and sign accounting reports. Finally, national organisation was seen as a means of raising the status of accounting professionals and placing them on a par with other professions, such as law. However, when the national body (the CFC) was created, its powers remained restricted to registering accountants and its terms of reference were enshrined in legislation. Unlike other cases, in Brazil, bookkeepers were not excluded from registration with the CFC. It may be speculated that this was because many of the accountants in positions of power within the government, were themselves bookkeepers. Even after the creation of the CFC, an openness prevailed, perhaps the result of the state not wishing to support closure as it would deny opportunities to those with practical experience in periods when their services were in demand. In the case of Brazil, syndicalism was intended to be a means of subordinating the occupational group into cooperation. However, the very means used by the state for the 
purposes of subordination created the conditions for subsequent reform of occupational associations as the political climate changed and the state's dominance declined. 


\section{Primary Sources: Decrees.}

Lei ${ }^{\circ}$ 556, de 25.06.1850. Código comercial.

Decreto 4.331, de 01.02.1902. Concede ao curso annexo á Academia do Commercio de Juiz de Fóra as vantagens de que gosa o Gymnasio Nacional. Library of Federal Senate in Brazilia.

Decreto 979, de 6.01.1903. Faculta aos profissionais da agricultura e indústrias rurais a organização de sindicatos para defesa de seus interesses. Library of Federal Senate in Brazilia.

Decreto 1.339, de 9.01.1905. Declara instituições de utilidade pública a Academia de Commercio do Rio de Janeiro, reconhece os diplomas por ella conferidos, como de caracter official; e dá outras providências. Library of Federal Senate in Brazilia.

\#__ Decreto $\mathrm{n}^{\mathrm{o} .}$ 1.637, de 5.01.1907. Crea syndicatos profissionais e sociedades cooperativas. Library of Federal Senate in Brazilia. http://legis.senado.leg.br/legislacao/ListaPublicacoes.action?id=55323\&tipoDocumento= DEC\&tipoTexto=PUB

\#___ Decreto 7.751, de 23.12.1909. Approva o regulamento expedido em virtude do art. 32 da lei n. 2.083, de 30 de julho de 1909, para execução dos serviços da Administração Geral da Fazenda Nacional. Library of Federal Senate in Brazilia.

\#__ Decreto 13.746, de 03.09.1919. Dá Instrucções para o serviço geral de contabilidade pública, em face da lei n. 2.083 de 30 de julho e decreto n. 7.751, de 23 de dezembro de 1909. Library of Federal Senate in Brazilia.

\#___ Decreto 4.536, de 28.01.1922. Organiza o Código de Contabilidade da União. Library of Federal Senate in Brazilia.

\#___ Decreto 17.329, de 28.05.1926. Approva, o regulamento para os estabelecimentos de ensino technico commercial reconhecidos officialmente pelo Governo Federal. Camara dos Deputados. Brazilia.

\#___ Decreto 19.402, de 18.11.1930. Cria uma Secretaria de Estado com a denominação de Ministério dos Negocios da Educação e Saúde Pública. Library of Federal Senate in Brazilia.

\#__ Decreto 20.158, de 30.08.1931. Organiza o ensino comercial, regulamenta a profissão de contador e dá outras providências. Library of Federal Senate in Brazilia.

\#__ Decreto 21.033, de 08.02.1932. Estabelece novas condições para o registo de contadores e guarda-livros, e da outras providências. Library of Federal Senate in Brazilia. 
\#___ Decreto 1.608, de 18.09.1939, que promulgou o Código de Processo Civil e unificou o direito processual e a jurisdição civil e comercial em uma jurisdição comum. Library of Federal Senate in Brazilia.

\#___ Decreto 2.416, de 17.07.1940. Aprova a codificação das normas financeiras para os Estados e Municípios

\#___ Decreto-Lei 2.627, de 26.09.1940. Dispõe sobre as sociedades por Ações. Library of Federal Senate in Brazilia. Library of Federal Senate in Brazilia.

\#___ Decreto-Lei 4.048, de 22.01.1942. Cria o Serviço Nacional de Aprendizagem dos Industriários (SENAI). Library of Federal Senate in Brazilia.

\#___Decreto-Lei 7.955, de 13.09.1945. Institui conselhos de medicina e da outras providencias. Etica profissional no exercício da medicina. Ministerio do Trabalho. Brasilia.

\#___ Decreto-Lei 7.988, de 22.09.1945. Dispões sobre o ensino superior de Ciências Econômicas e de Ciências Contábeis e Atuariais. Library of Federal Senate in Brazilia.

Decreto-Lei 8.191, de 20.11.1945. Disposições relativas ao curso comercial básico e a seus atuais alunos de terceira e quarta series. Library of Federal Senate in Brazilia.

\#__ Decreto-Lei 8.622, de 10.01.1946. Dispõe sobre a aprendizagem dos comerciários, estabelece deveres dos empregadores e dos trabalhadores menores relativamente a essa aprendizagem e dá outras providências. Library of Federal Senate in Brazilia.

Decreto-Lei 9.295, de 27 de maio de 1946. Cria o Conselho Federal de Contabilidade, define as atribuições do Contador e do Técnico em Contabilidade, e dá outras providências. Library of Federal Senate in Brazilia.

\#__ Decreto 15.601, de 26.01.1946. Código de processo civil. Library of Federal Senate in Brazilia.

\#__ Resolução $\mathrm{n}^{\circ}$ 2, de 23.04.1934. Aprova a organização dos Conselhos Regionais de Engenharia e Arquitetura. Conselho Regional de Engenharia e Agronomia-CONFEA.

\#___ Resolução CFC no 3, de 29.10.1946. Regulamentação da profissão do contador. Biblioteca do Conselho Federal de Contabilidade. Brazilia.

\#___ Resolução CFC no 853, de 29.10.1999. Institui o exame de suficiência como requisito para obtenção de registro profissional em $C R C$. Biblioteca do Conselho Federal de Contabilidade. Brazilia. 
\# Resolução CFC no 928, de 29.10.2002. Altera a Resolução n CFC 853/99 que institui o Exame de Suficiência como requisito para obtenção de registro profissional em CRC. Código de Ética Profissional do Contabilista. Library of the Regional Council of Minas Gerais.

\section{Foreign language references and resources}

Anuário Estatístico do Brasil, 1939-40, p.1312, IBGE.Instituto Brasileiro de Estatística e Geografia.

Anuário Estatístico do Brasil, 1941-45,p.59, IBGE.Instituto Brasileiro de Estatística e Geografia.

Aragon AP. Estrutura Conceitual Básica da Contabilidade. Universidade Norte do Paraná 2009.

Boletim Estatístico do Brasil 1946; 4(13). IBGE.Brasilia.

Bielinski AC. Educação profisssional no século XIX. Curso Comercial do Liceu de Artes e Ofícios: um estudo de caso 2000 http://www.se

Boito Jr A. "Reforma e persistência da estrutura sindical in Boito Jr., A. O sindicalismo brasileiro nos anos 90. Rio de Janeiro, Paz e Terra. 1991.

Centro de Memórias do Conselho Regional de Contabilidade do Rio Grande do Sul 2009.

Conselho Regional de Contabilidade do Rio de Janeiro (CRCRJ). Portal Dia do Contador. http://www.crc.org.br/crcrj/crc.asp.

Goldsmith RW. Brasil 1850-1984: Desenvolvimento Financeiro sob um século de inflação, São Paulo: Harper \& How; 1986.

Journal Correio da Manha, no. 2, 20 de Maio de 1917. Rio de Janeiro.

Leite CEB. A evolução das ciências contábeis no Brasil. FGV, Rio de Janeiro; 2005.

Lopes de Sá A. Perícia Contábil 5ª edição, São Paulo: Atlas; 2002.

Lopes de Sá A. Historia geral da contabilidade no Brasil Brasilia: Conselho Federal de Contablidade (CFC); 2008.

Masi V. Francisco D'Áuria e a contabilidade contemporânea. Revista Paulista de Contabilidade 1958; 379:8-9.

MBC - Mensário Brasileiro de Contabilidade, n. 4, July, 1917.

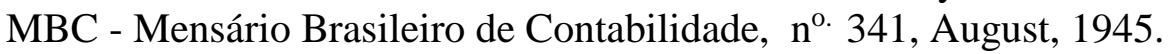

Minuta do IV Congresso Brasileiro de Contabilidade, 1937. Biblioteca do Sindicato dos Contabilista do Município do Rio de Janeiro.

Nagle J. Educação e Sociedade na Primeira República. São Paulo: EPU/FENAME; 1976.

Oliveira OMBA. O sindicalismo brasileiro e as práticas anti-sindicais, Revista Sequencia, 2005; July: 50: 29-48

Peleias IR, Bacci J. Pequena cronologia do desenvolvimento contábil no Brasil: Os primeiros pensadores, a padronização contábil e os congressos brasileiros de contabilidade. Revista Administração 2004, 5(3): 39-54. FECAP.

Pires MAA. Perícia Contábil - Reflexões sobre seu verdadeiro significado e importancia. Contabilidade Vista \& Revista, 1999; 10(1), March. Library of the Regional Council of Minas Gerais.

Portal do Conselho Regional de Contabilidade do Rio de Janeiro (CRCRJ). 
RBC - Revista Brasileira de Contabilidade. Cinquentenário da criação do CFC e CRCs. 1996; Ano XXV (99), Maio/Junho. Library of the Regional Council of Rio de Janeiro.

RBC - Revista Paulista de Contabilidade. Prefácio. March/April.1932. Library of the Syndicate of Accountants of the County of Rio Grande do Sul.

Relatório do Primeiro Congresso Brasileiro de Contabilidade de 1924 (1927), Imprensa Nacional (1), Rio de janeiro. Library of the Syndicate of Accountants of the County of Rio de Janeiro.

Relatório do Primeiro Congresso Brasileiro de Contabilidade de 1924 (1929), Imprensa Nacional, 1/2: 1-800, Rio de janeiro. Library of the Syndicate of Accountants of the County of Rio de Janeiro.

Tavares MC. Auge e declínio do processo de substituição de importações no Brasil, 1972 in: Tavares, M.C. Da substituição de importações ao capitalismo financeiro. Rio de Janeiro: Editora Zahar; 1977

Vianna SB. Villela A. O pós-Guerra (1945-1955) in Giambiagi, F. et al., Economia Brasileira Contemporânea (1945-2004). Elsevier, Rio de Janeiro; 2005.

Werebe MJG. Grandezas e Misérias do Ensino no Brasil. Ed. Difusão, São Paulo; 1970.

Yoshitake M, Pires MA, Sousa MS, Filho NSR. O Perfil profissional do Perito Judicial Contábil. Paper presented at the 19th Convenção dos Contabilistas do Estado de São Paulo. São Paulo, $8^{\text {th }}$ September, 2005.

\section{$\underline{\text { References }}$}

Annisette M. Importing accounting: The case of Trinidad and Tobago. Accounting Business and Financial History 1999; 9(1): 103-133.

Annisette M. Imperialism and the Professions: The Education and Certification of Accountants in Trinidad and Tobago. Accounting Organizations and Society 2000; 25(7): p. 631-659.

Bailey D. The attempt to establish the Russian accounting profession 1875-1931. Accounting, Business and Financial History 1992; 2: 1-23.

Bak JL. Political centralisation and the building of the interventionist state in Brazil: Corporatism, regionalism and interest group politics in Rio Grande do Sul, 19301937. Luso-Brazilian Review 1985; 22(1): 9-25.

Bakre OM. The emergence of the accounting profession in developing countries: The case of Jamaica: Unpublished $\mathrm{PhD}$ thesis. University of Essex.; 2001.

Bakre OM. First attempt at localising imperial accountancy: The case of the Institute of Chartered Accountants of Jamaica (1950s-1970s). Critical Perspectives on Accounting 2005; 16(8): 995-1018.

Bunget O, Farcane N, Dumitrescu A, Popa A. The accounting profession and professionist in Romania. Munich Personal RePEc Archive 2009; Paper number 18408.

Burns EB. A history of Brazil. Columbia University Press, New York; 1993.

Caramanis C. The interplay between professional groups, the state and supranational agents: Pax Americana in the age of 'globalisation'. Accounting, Organisations and Society 2002; 27(4/5): 379 - 408. 
Carnegie GD, Edwards JR. The construction of the professional accountant : The case of the Incorporated Institute of Accountants, Victoria (1886). Accounting, Organisations and Society 2001; 26(4/5): 310 - 325.

Cawson A. Organised interests and the state in Studies in meso-corporatism. Sage Publications, 1985.

Chua W, Poullaos C. Rethinking the profession-state dynamic: The Victorian chartered attempt. Accounting, Organisations and Society 1993; 18(7/8): 691-782.

Coleman WD. State corporatism as a sectoral phenomenon: The case of the Quebec construction industry in Studies in meso-corporatism. Sage Publications, 1985.

Colistete RP. Productivity, Wages, and Labor Politics in Brazil, 1945-1962, The Journal of Economic History, 67: 93-127, Cambridge University Press; 2007.

Conniff M. Urban Politics in Brazil - The rise of populism - 1925-1945. London; 1981.

Cooper D, Puxty T, Lowe T, Willmott H. The Accounting Profession, Corporatism and the State, in Chua WF, Lowe T. Puxty T. (eds), Critical Perspectives in Management Control 1989. Macmillan, London.

Cooper D, Robson K. Accounting, professions and regulation: Locating the sites of professionalisation. Accounting, Organisations and Society 2006; 31:415-444.

De Beelde I. Creating a profession 'out of nothing'? The case of the Belgian auditing profession. Accounting, Organisations and Society 2002; 27(4/5): 447-470.

Dedoulis E, Caramanis C. Imperialism of influence and the state-profession relationship: The formation of the Greek auditing profession in the post-WWII era. Critical Perspectives on Accounting 2007; 18: 393-412.

Dyball MC, Poullaos C, Chua W. Accounting and empire: Professionalisation-asresistance The case of Philippines. Critical Perspectives on Accounting 2007; 18: 415-449.

Fausto B. A concise history of Brazil. Cambridge: Cambridge University Press; 1999.

Flynn P. Brazil: A Political Analysis. Benn and Westview Press, London; 1978.

French J. The origin of corporatist state intervention in Brazilian industrial relations, 1930-1943: A critique of the literature. Luso-Brazilian Review 1991; 28(2): 1326.

Hao ZP. Regulation and organisation of accountants in China. Accounting, Auditing \& Accountability Journal, 1999; 12(3): 286-302.

Johnson TJ, Caygill M. The development of accountancy links in the Commonwealth. Accounting and Business Research, 1971; 1(2): 155-173.

Johnson TJ. Professions and Power. Macmillan, London; 1972.

Johnson TJ. The state and the professions: peculiarities of the British, in "Social class and the division of labour" by A.Giddens and G Mackenzie (eds), Cambridge University Press; 1982.

Larson MS. The rise of professionalism: A sociological analysis: University of California Press; 1977.

Lee TA. The professional journal as a signal of movement to occupational ascendancy and as legitimation of a professional project: The early history of the Accountant's Magazine 1897-1951. Accounting History 2006; 11(1): 7-40.

Loewenstein K. Brazil under Vargas. Macmillan, New York; 1942.

Macdonald K. The sociology of the professions. Sage, London; 1995.

Mcoy B. Education in Brazil. Journal of Education 1959. July, 37(1): 39-43. 
Miller P. On the interrelations between accounting and the state. Accounting, Organisations and Society, 1990; 15(4): 315-338.

Panitch L. The development of corporatism in liberal democracies, in "Trends towards corporatist intermediation" (edited by P.C. Schmitter and G.Lehmbruch). Sage Publications; 1979.

Panitch L. Recent theorisations of corporatism: Reflections on a growth industry. British Journal of Sociology, 1980; 31(2):159-187.

Peláez CM. The theory and reality of imperialism in the coffee economy of nineteenthcentury Brazil. The Economic History Review 1976; 29(2): 276-290.

Puxty AG, Willmott HC, Cooper DJ, Lowe T. Modes of regulation in advanced capitalism: Locating accountancy in four countries. Accounting, Organizations and Society 1987; 12(3): 273-291.

Ramirez C. Understanding social closure in its cultural context : Accounting practitioners in France (1920-1939). Accounting, Organisations and Society 2001; 26(4/5): 391418.

Richardson AJ. Corporatism and intraprofessional hegemony: A study of regulation and internal social order. Accounting, Organisations and Society 1989; 14(5/6): 415431.

Rodrigues LL, Gomes D, Craig R. Corporatism, liberalism and the accounting profession in Portugal since 1755. Accounting Historians Journal 2003; 30(1): 95-127.

Rodrigues LL, Schmidt P, Santos JL. The Origins of Modern Accounting in Brazil: Influences Leading to the Adoption of IFRS. Research in Accounting Regulation, 2012; 24(1): 15-24.

Rodrigues LL, Schmidt P, Santos JL, Fonseca P. A research note on accounting in Brazil in the context of political, economic and social transformations, 1860 - 1964. Accounting History, 2011; 16 (1): 111-123.

Roslender R. Sociological perspectives on modern accountancy. Routledge, London; 1992.

Sakagami M, Yoshimi H, Okano H. Japanese accounting profession in transition. Accounting, Auditing and Accountability Journal 1999; 12(3): 340-357.

Schmitter PC. Interest conflict and political change in Brazil. Stanford, California: Stanford University Press; 1971.

Schmitter PC. Still the century of corporatism? Review of Politics 1974, p.85-131.

Schmitter PC. Still the century of Corporatism? in "Trends towards corporatist intermediation" by P.C. Schmitter and G.Lehmbruch (eds). Sage Publications; 1979.

Seal W, Sucher P, Zelenka I. Post-socialist transition and the development of an accountancy profession in the Czech Republic. Critical Perspectives on Accounting 1996; 7: 485-508.

Sian S. Inclusion, exclusion and control: The case of the Kenyan accounting professionalisation project. Accounting, Organisations and Society 2006; 31(3): 295-322.

Sian S. Operationalising closure in a colonial context: The Association of Accountants in East Africa, 1949-1963. Accounting, Organisations and Society 2011; 36 (6): 363381. 
Sikka P, Willmott $\mathrm{H}$. Illuminating the state-profession relationship: Accountants acting as Department of Trade and Industry investigators. Critical Perspectives on Accounting 1995a; 6: 341-369.

Sikka P, Willmott H. The power of "independence": Defending and extending the jurisdiction of accounting in the United Kingdom. Accounting, Organisations and Society 1995b; 20(6): 547-581.

Skidmore TE. Brazil: Five centuries of change. Oxford: Oxford University Press; 1999.

Spiegel HW. The Brazilian Economy. Chronic inflation and sporadic industrialization. Blakiston Co.: Philadelphia, Toronto; 1949.

Streeck W, Schmitter PC. Private interest government: Beyond market and state. London: Sage; 1985a.

Streeck W, Schmitter PC. Community, market, state - and associations? The prospective contribution of interest governance to social order. European Sociological Review 1985b; 1(2): 119-138.

Uche CU. Professional accounting development in Nigeria: threats from the inside and outsideI. Accounting, Organisations and Society 2002; 27(4/5): 471- 496.

Verma S, Gray SJ. The setting up of the Institute of Chartered Accountants of India: A first step in creating an indigenous accounting profession. Accounting Historians Journal 2006; 33(2): 131-156

Walker SP, Shackleton K. Corporatism and structural change in the British accountancy profession, 1930-1957. Accounting, Organisations and Society 1995; 20(6): 467503.

Williams D. Culture wars in Brazil: The first Vargas regime, 1930-1945. Durham, NC: Duke University Press; 2001.

Willmott $\mathrm{H}$. Organising the profession: A theoretical and historical examination of the development of the major accountancy bodies in the U.K. Accounting, Organisations and Society 1986; 11(6): 555-580.

Yee $\mathrm{H}$. The re-emergence of the public accounting profession in China: A hegemonic analysis. Critical Perspectives on Accounting 2009; 20: 71-92.

Yee $\mathrm{H}$. Analyzing the state-accounting profession dynamic: some insights from the professionalization experience in China. Accounting, Organizations and Society 2012; 37(6): 426-444.

Zelinschi D. Legitimacy, expertise and closure in the Romanian accountant's professional project, 1900-16. Accounting History 2009; 14(4): 381-403.

Zimmermann J. Volmer P. and Werner J. New Governance Modes for Germany's Financial Reporting System. TranState Working Papers, 34. Bremen: Sfb 597 Staatlichkeit im Wandel. 2006. ISSN 1861-1176. 